\title{
Large Classes and English Language Teaching and Learning in Public Sector Secondary Schools of Pakistan
}

\author{
Shagufta Moghal1, Asma Shahid Kazi ${ }^{1}$, Ammaira Bukhari ${ }^{1}$ \\ ${ }^{1}$ Lahore College for Women University, Pakistan
}

\begin{abstract}
This study aimed to explore the Pakistani secondary teachers' perceptions towards teaching English in large classes and to find out how they coped with the challenges which come with teaching such classes. The data was collected through semi structured interviews, with eight secondary school teachers currently working in the public sector schools of Lahore, Pakistan. The data was analyzed inductively through repeated engagement with the interview transcripts. Research results indicated that teaching large classes had many issues and problems, such as lack of space, facilities and resources; inability to pay attention to every student; high noise levels; time constraints; problems with assessment of a large number of students; and limited opportunities of interaction between teacher-student and studentstudent. The discussion highlighted the teaching and learning strategies employed by teachers in their classrooms in the Pakistani context, which include the use of pair and group work, notional time, peer correction and self-editing to improve assessment.
\end{abstract}

Keywords: English as a foreign language Large classes, Public Sector Education, Secondary Education

\section{INTRODUCTION}

Large and overcrowded classrooms are a reality in the educational context of south Asian countries like Pakistan. Hayes (1997) states that although there is no definitive quantitative definition of what exactly an overcrowded class is, the ideal class size is, or should be, not more than 30 students. A classroom is said to be overcrowded in which the number of students exceeds the optimum level such that it causes hindrance in the teaching-learning process. A research study conducted in Pakistan by Khan and Iqbal (2012) found 'the average number of students in most (Pakistani) classrooms ranges from 70 to $120^{\prime}$ (p.162). They claimed that effective teaching was not possible in overcrowded classes and most of the teachers were facing instructional, discipline, physical and evaluation problems; this problem is magnified when dealing with language education, where acquisition of a foreign language is the expected outcome.

Overcrowded classes have become one of the most serious problem faced by schools and teachers, especially is language education. Ideally, class size 
would be capped at 20-25 students especially for English as a foreign language class (Tayeg, 2015). In Pakistan, unfortunately, many classrooms now regularly exceed forty-five students, especially in public sector schools. This paper aimed to investigate whether according to the perceptions of the language instructors and teacher, overcrowded classrooms were a barrier in the progressive activities of classroom teaching- learning process.

\section{Research Questions}

1. How do the Pakistani Secondary teachers perceive problems of large classes in the ELT context?

2. What teaching strategies are employed by secondary school teachers when dealing with large classes?

\section{LITERATURE REVIEW}

Overcrowded or large classrooms are not a new phenomenon; over the last two decades research has focused on the impact and repercussions of teaching students in crowded and large cases (see Burnett,1995; Earthman, 2002; Emmer \& Stough, 2001; Khan \& Iqbal, 2012; Marais, 2016; Onwu \& Stoffels, 2005). These researchers have found that large classes are characterized by certain common problems including: the physical environment of the classroom, the issue of management, students' engagement in the learning process, difficulties of assessing student's knowledge and feedback, and the problem of teaching resources. Additionally, in such classrooms, teachers may spend most of their time trying to gain students' attentiveness or concentrating on classroom management activities to regulate students' activities in a proper way.

Lewit and Baker (2000) researched overcrowded schools in New York City and found that 75 percent of teachers said that overcrowding affected classroom activities and 70 percent shared that overcrowding modified and influenced their instructional techniques. Wedell and Malderez (2013) highlighted three problems related to the physical environment of the classroom; firstly, the shortage of furniture and teaching resources and facilities; secondly, hindrances in circulation and movement, which in turn affects how teachers monitor the students, leading to lack of understanding, attentiveness and cheating in assigned tests and tasks; and thirdly, effect on communication, or lack of interaction.

According to Earthman (2002), and Harbaugh and Cavanagh, (2012), classroom characteristics directly influence students' self-esteem including their educational values, learning outcomes and classroom learning. Other researches have also highlighted how large class sizes affect quality learning and achieving the teaching-learning objectives (Burnett, 1995; Yaman, 2009). Earthman (2002) found that overcrowded classroom conditions hinder teachers' attention to individual students and slows down the progress of students' learning; it was also noted that in such classrooms, teachers 'only had time to cover the basic lessons and could not spend extra time with slow learners' (p. 11).

Renaud, Tannenbaum and Stantial (2007), investigating large classes in Haiti, noted that many students in the developing countries do not have textbooks and other learning resources. They sometimes have notebooks and a pen/pencil 
which they bring with them. The teachers use blackboards and chalk for teaching but usually do not have access to photocopiers, printing and computers. English dictionary or English grammar books are also not easily available in such teaching learning contexts.

Hayes (1997) has identified five issues and problems in teaching in large classes, namely, discomfort caused by the physical constraints; discipline and control problems and difficulties, lack of individual attentions; challenges and difficulty in effective evaluation; and, problems of charging learning effectiveness. The researchers also encountered challenges such as monitoring attendance, checking assignments, maintaining discipline, checking comprehension, and many other problems with specific reference to language teachers involved in large class teaching.

Sariçoban and Sakizli (2006) have also drawn attention to the fact that it is crucial to recognize that the physical environment can influence the way teachers and students think and behave. The mode of teaching and method of instruction is affected by the size of the class, as indicated by a research by Harfitt's (2012) claim that in small classes teachers are likely to ask open-ended questions which may lead to more interaction between teachers and their students, whereas in large classes teachers are likely to ask their learners closed questions that might not support learners' discussion with their teachers or with other students. A possible reason for teachers in large classes choosing closed questions instead of open ones is that closed questions allow the teacher to have more control over the answers. Besides, closed questions are also less time consuming in terms of providing feedback.

Sarwar (2001) worked extensively on individualization techniques for large classes in English language in Pakistan. She felt that in the Pakistani context class size was not likely to be reduced, and thus there had to be more realistic solutions. Her research "addressed three major ELT problems: large classes, the dependent learner, and lack of exposure to real-world English" (p.135). Seeing the results of the research, she has suggested replicating the technique to overcome persisting issues faced in teaching large classrooms.

In view of above literature review, the main goal of this study is to explore the Pakistani secondary teachers' perception towards teaching English in large classes and to find out the practical methodology to teach English in such context. The research questions and methodology for is presented in the subsequent sections of this paper.

\section{RESEARCH METHOD}

For collecting the data, this exploratory qualitative research employed semi structured interviews of eight Pakistani secondary English teachers from four public sector schools in Lahore. Basic demographic information regarding the participants such as their teaching experience, qualification, grades taught, workload and class strength. The researcher after taking personal information from each participant, then asked more open- end questions regarding their perceptions about the preferred teaching methodology, class management strategies and their opinion of the ideal class size. 
Most public secondary schools in Pakistan have about four or five English teachers due to the large number of classes in this level. Four schools were selected randomly from Lahore, from which eight participants were conveniently selected teaching English to grades nine and ten. After presenting the research plan to all English teachers, two teachers from each school were asked to join the research as they were interested to take part. Therefore, four teachers from grades nine and ten from each school were interviewed. In the schools selected, English was taught only by female teachers.

\section{FINDINGS AND DISCUSSION}

Analysis of the data revealed that all participants had taught classes which they consider large, consisting of forty to fifty students, and had no experience of teaching smaller ones. They were used to teaching classes with limited space and insufficient technical materials as tapes, tape recorder and other supplementary resources. Some participants had an experience of teaching for 10 years and more, in teaching English to large classes. Such experience seemed to be a significant factor in shaping the teachers' perceptions about large classes and the way they deal with them. All participants were interviewed once where the questions concentrated on their experience in teaching large classes in secondary level, the challenges they encounter and the strategies they employ to overcome the problem.

Analysis of the responses to the first research question regarding teachers' perception of problems in large classes revealed that most of the participants held the following perceptions which they felt hinder the effectiveness of learning and teaching process:

Table 1. Teacher Perceptions about Problems in Teaching Large Classes

\begin{tabular}{lc}
\hline \multicolumn{1}{c}{ Problems of large classes } & Respondents \\
\hline $\begin{array}{l}\text { Large classes with limited space do not allow teachers to move around freely to } \\
\text { monitor, observe and assess students during activities. }\end{array}$ & 8 \\
\hline $\begin{array}{l}\text { Impossible to pay attention to each and every student } \\
\text { Many students are disrespectful towards teachers and peers }\end{array}$ & 6 \\
\hline $\begin{array}{l}\text { Class size affects student performance, due to misbehavior, low attendance and } \\
\text { other disciplinary problems in large classes }\end{array}$ & 7 \\
$\begin{array}{l}\text { Teachers cannot utilize a variety of methods, such as higher-order questioning } \\
\text { and active learning approaches }\end{array}$ & 8 \\
$\begin{array}{l}\text { Teaching in overcrowded classrooms takes a toll on the teacher's ability to } \\
\text { manage time. }\end{array}$ & 7 \\
$\begin{array}{l}\text { Overcrowding has a variety of disruptive consequences for learner behaviour. } \\
\text { For example, "learners cannot pay attention or participate at the required level } \\
\text { of intensity because classmates are noisy." }\end{array}$ & 7 \\
$\begin{array}{l}\text { Time management. 'Teachers only had time to cover the basic lessons and } \\
\text { could not spend extra time with slow learners" }\end{array}$ & 6 \\
$\begin{array}{l}\text { Students do not respond to the teacher's question and wait for the teacher to } \\
\text { provide most answers to questions on worksheets and exercises } \\
\text { Teachers do not have the time to give remedial work to students who miss } \\
\text { classes }\end{array}$ & 6 \\
$\begin{array}{l}\text { Great amount of time is spent on setting assessment tasks, marking and } \\
\text { providing feedback. }\end{array}$ & 8 \\
\hline
\end{tabular}


There were varied responses by the participants regarding the second research question entailing teaching strategies employed by secondary school English language teachers when dealing with large classes. They attributed class size as the main reason for little engagement with the classroom activities. All of them felt teachers in large classes tend to use mainly a teacher-centered approach, using lecture style and closed questions, whereas teachers in small classes tend to use a variety of methods and open questions, which are more student-centered. For effective teaching interaction between teacher and pupil is necessary. This finding reinforced the results of research by Harfitt's (2012), who claimed that teachers in large classes asked their learners closed questions that might not support learners' discussion with their teachers or with other students.

Results report interactions between teachers and pupils were found to be minimal. Most of the time, teachers were not involving pupils in lesson preparations. The teaching methods used by teachers were not pupil centered, but teacher centered. The classroom sitting arrangement did not allow interactive methods. Likewise, the study revealed that pupils had no opportunity for meeting their subject teacher to get academic assistance after the class hours. This is in accordance with the findings by Earthman (2002), who linked overcrowded classrooms to lack of attention on individual students, thus affecting their progress and achievement.

Group tasks were tried by five respondents and were not successful as "inevitably only one or two students did the work and the rest didn't" reported one respondent. Another teacher responded that in group activity "there are passive participants who just want to cheat from others work". Pair checking is not always fair was the opinion of a majority. "It is impossible to cater to individual learners", was another opinion given by a teacher, endorsed by six of the others.

An interesting fact pointed out by all the teachers was that translating from the target language to the native language took up a lot of teaching time. Analysis also showed that half of the teachers felt that a lot of time was spent on reviewing previously learnt concepts, and review was a necessary strategy. Translation strategy has also been pointed out as a problem for teaching large classes by Setati, Adler, Reed and Bapoo (2002).

According to participants, there are certain course requirements where overcrowded classes are problem. One such problem is students' oral expression when interacting with teachers and peers. It is a challenge to talk to everybody in class, to ensure that everybody is participating, and to evaluate all of them fairly. In written expression, the problem is even worse, because students are given a writing task, in one hour they can just monitor or check just over half of the class only.

The participants also discussed the strategies which they used to deal with the problems and challenges they faced daily. They believed that flexibility in time and lesson spans would help them manage lessons effectively. To overcome the issue of time, the concept of notional time has proven to be successful in the South African context; according to Spady and Schlebusch (1999) "notional time is not fixed or set, which means that its introduction to the daily or weekly timetable brings a greater element of flexibility so that learning is less 
compartmentalized and rigid". This strategy may help teachers work more effectively in large classes.

The participants also emphasized the importance of group work and project work to enhance student engagement; the outcome of the group tasks or projects usually tangible and easy to assess and mark. The participants also believed that their students displayed more creativity and motivation when presented with group or collaborative tasks, and often performed better in assessment for such tasks too. Renaud et al. (2007) too has proposed two techniques to help teachers assess their students effectively; the first involves making students work together to produce one piece of writing for each group or to complete grammar exercises together, which reduces the number of tasks a teacher must assess. The second technique involves self-editing, followed by one or two rounds of peer editing before the students turn in their work. These techniques may easily be employed in the Pakistani secondary schools.

This also matches what Sarwar (2013) has proposed that by using the individualized learning strategies and increasing learner autonomy, the burden of the teacher at levels may be lessened, in addition to turning the learners into autonomous, lifelong and self-motivated learners. The findings and suggestions which resulted from this study may be used to inform and prepare school teachers to be better equipped in dealing with large classes, and an overpowering number of responsibilities associated with teaching such classes.

\section{CONCLUSION}

This study aimed at investigating the explore the Pakistani secondary teachers' perception towards teaching English in large classes and to find out how they coped with the challenges which come with teaching such classes. The data was collected through semi structured interviews, with eight secondary school teachers currently working in the public sector schools of Lahore, Pakistan. The data was analyzed inductively through repeated engagement with the interview transcripts. Research results indicated that the findings are in accordance with the research conducted in other countries, both with similar and dissimilar contexts. Large classes come with many issues and problems, such as lack of space, facilities and resources; inability to pay attention to every student; high noise levels; time constraints; problems with assessment of a large number of students; and limited opportunities of interaction between teacher-student and studentstudent. The discussion highlighted the teaching and learning strategies employed by teachers in their classrooms; these strategies include use of pair and group work, utilizing individualized learning strategies and enabling learners to work autonomously and independently. The results have reinforced the idea that teaching large classes may appear as a problem but is not an insurmountable challenge; the negative effects of teaching and learning in large classes may be reduced if teachers make use of notional time, peer correction and self-editing to improve assessment. 


\section{REFERENCES}

Burnett, G. (1995). Overcrowding in urban schools. ERIC/CUE Digest Number, $107,1-6$.

Earthman, G. I. (2002). School Facility Conditions and Student Academic Achievement. UCLA: 's Institute for Democracy, Education, and Access. Retrieved from https://escholarship.org/uc/item/5sw56439

Emmer, E. T., \& Stough, L. M. (2001). Classroom management: A critical part of educational psychology, with implications for teacher education. Educational Psychologist, 36(2), 103-112.

Englehart, J. M. (2011). Why class size effects cannot stand alone: Insights from a qualitative exploration. Learning Environments Research, 14(2), 109-121.

Finn, J. D., Pannozzo, G. M., \& Achilles, C. M. (2003). The "why's" of class size: Student behavior in small classes. Review of Educational Research, 73(3), 321-368.

Harbaugh, A. G., \& Cavanagh, R. F. (2012). Associations between the Classroom Learning Environment and Student Engagement in Learning 2: A Structural Equation Modelling Approach. Australian Association for Research in Education (NJ1).

Hattie, J. (2005). The paradox of reducing class size and improving learning outcomes. International Journal of Educational Research, 43, 387-425.

Hayes, D. (1997). Helping Teachers To Cope with Large Classes. ELT Journal, 51(2), 106-16.

Heppner, F. (2007). Teaching the large college class: A guidebook for instructors with multitudes. New York: Jossey-Bass.

Khan, P., \& Iqbal, M. (2012). Overcrowded classroom: A serious problem for teachers. University of Science and Information Technology, 49, 1016210165.

Lewit, E. M., \& Baker, L. S. (2000). Class Size. Future Child, 7 (3), 12-21

Marais, P. (2016). "We can't believe what we see": Overcrowded classrooms through the eyes of student teachers. South African Journal of Education, $36(2)$.

Miller-Whitehead, M. (2003). Compilation of class size findings: Grade level, school and district. Paper presented at the Annual Meeting of the Midsouth Educational Research Association.

Mulryan-Kyne, C. (2010). Teaching large classes at college and university level: Challenges and opportunities. Teaching in Higher Education, 15(2), 175185 . 
Onwu, G., \& Stoffels, N. (2005). Instructional functions in large, under-resourced science classes: perspectives of South African teachers: research article: general. Perspectives in Education, 23(1), 79-91.

Renaud, S., Tannenbaum, E., \& Stantial, P. (2007). Student-Centered Teaching in Large Classes with Limited Resources. English Teaching Forum, 45(3), 12.

Rivera-Batiz, F. L., \& Marti, L. (1995). A School System at Risk: A Study of the Consequences of Overcrowding in New York City Public Schools. IUME Research Report No. 95-1.

Sarıçoban, A., \& Sakızlı, S. (2006). Factors influencing how teachers manage their classrooms. Journal of Language and Linguistic Studies, 2(1).

Sarwar, Z. (2013). Adapting individualization techniques for large classes. In Hall, D.R. \& Hewings, A. (Eds.), Innovation in English Language Teaching: A Reader (127-136). London: Routledge.

Setati, M., Adler, J., Reed, Y., \& Bapoo, A. (2002). Incomplete journeys: Codeswitching and other language practices in mathematics, science and English language classrooms in South Africa. Language and education, 16(2), 128-149.

Spady, W. \& Schlebusch, A 1999. Curriculum 2005. A guide for parents. Cape Town: Renaissance.

Tayeg, A. (2015). Les difficultés à la pratique de l'hypnose en médecine générale: Etude qualitative par focus group auprès de médecins généralistes d'Ile-deFrance (Doctoral dissertation).

Yaman, H. (2009). Teachers' Views on the Applicability of the Turkish Course Curriculum in Crowded Primary Classrooms. Educational Sciences: Theory and Practice, 9(1), 349-359. 